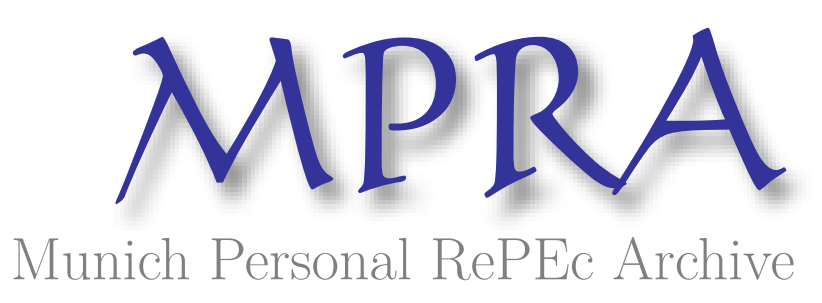

\title{
Investigation of methods of counteracting corporate fraudulence: accounting-legal approaches to the identification of abusonment
}

Plikus, Iryna

Sumy State University

2017

Online at https://mpra.ub.uni-muenchen.de/85470/

MPRA Paper No. 85470, posted 27 Mar 2018 15:15 UTC 
UDC 657.37:343

Plikus I.

\section{Investigation of methods of counteracting corporate fraudulence: accounting-legal approaches to the identification of abusonment}

Запропоновано створення власного агентства з фінансових розслідувань на підприємстві, його організаційну структуру, функиії, етапи виявлення фактів зловживань та таблиия індикаторів зловжсивань. Визначено місие фальсифікаиії фінансової звітності у фінансовому шахрайстві. Обтрунтовано необхідність оцінки ризику фальсифікаиії фінансової звітності та наведено найбільш суттеві ризики шахрайства з фінансовою звітністю.

Ключові слова: корпоративне шахрайство, фальсифікаиія фінансової звітності, оиінка ризиків шахрайства, Агентство фінансових розслідувань.

\section{Introduction}

The business environment in which businesses operate is characterized, on the one hand, by growing globaliza- tion, increased control over compliance with legislation and responsibility to society, and on the other - eco- nomic risks, one of which is corporate fraud and whose trend is worldwide, including in Ukraine, is sustainable and reduce- to:

1) theft of assets (typical schemes of Ukrainian com- panies are theft of money, assets, other illegal actions with assets);

2) corruption (manifested in obtaining undue bene- fits as a result of abuses with receivables and payables, fraudulent discounts, overwhelming payment of bills in favor of counterparties);

3) manipulations with reporting and accounting da- ta (for Ukraine are not so common, as a rule, manipula- tions occur because of the desire to appear better in the eyes of the investor, bank or shareholder).

The ACFE study conducted in 2016 showed that in $23.2 \%$ of cases, fraud losses in enterprises were $\$ 1$ mil- lion. And more, the longer the period of fraud lasts, the more serious the financial damage from and the losses grow proportionally to an increase in this, so the schemes that lasted more than 5 years led to losses of $\$ 850000$, it is also indicated that $2 / 3$ of the cases, which became known, related to the closed (average loss of $\$ 180.000$ ) or open joint-stock companies (average losses - \$ 178000) [1]. As for Ukraine, according to the audit firm PwC (Pricewater- houseCoopers), in 2014 more than $60 \%$ of all Ukrainian companies suffered from fraudulent activities, whereas in $2011-36 \%$, while about $18 \%$ of cases the amount of theft is from $\$ 100$ thousand to $\$ 1$ million [2]. According to KPMG in 2016, more than $90 \%$ of fraudulent actions by company employees are due to, or complete lack of internal control $(71 \%)$, or its shortcomings $(10 \%)$ [3]. Therefore, it is vital to study the issues related to the organization of an effective system of countering fraud.

\section{The object of research and its technological audit}

The updated framework for organization, implementa- tion and operation of internal control systems and eva- luation of their effectiveness (published in 2013 by the Committee of Sponsoring Organizations of the Treadway Commission COSO), which in force since December 2014, explicitly state that «in assessing risks that can hinder to achieve the set goals, the organization takes into account the likelihood of fraudulent activities» [4]. That is, one of the key components of an effective anti-fraud program is the assessment of fraud risk. At the same time, it is necessary to take into account that the risks of fraud are always growing in an environment of ineffec- tively controlled environment, and it is not enough to use standard audit methods to detect fraud and risks of fraud, since fraud in most cases is accompanied by well thought out schemes, even in existing «risk libraries» (KPMG, PwC, Ernst \& Young, Deloitte), it is not always possible to find adequate, sufficiently detailed solutions for identifi- cation and ways of identifying risks. According to KPMG research in 2016, most corporate crimes are provided by the Corporate (Financial) Security Service of the enter- prise, and only $6 \%$ of abuses are by the Internal Audit Service [3]. In this connection, let's note that recently foreign experts on financial investigation, audit and accounting considering the problems of interaction between the corporate security service and internal audit (control) are increasingly using the term as a criminal audit, fo- rensic audit, financial investigations, Forensic and draw attention to the appropriateness of using forensic methods in internal audit [59], and also focus on the legal un- derstanding of the signs of crime in the system of deci- sion making and key business processes by which it is possible to determine the available facts of fraud in the accounting system and point to such fraud as falsifica- tion of financial statements, which, as compared to other types of corporate fraud, usually causes more financial 
losses and has a more negative impact on shareholders and investors $[10,11]$.

\section{The aim and objectives of research}

The aim of research is justification of the feasibility of creating its own agency for financial investigations of corporate fraud in order to improve monitoring and pre- vention of fraud risks and identification of the risks of falsification of financial statements in order to develop mechanisms to reduce the risk of falsification of financial statements due to conflicts of professional judgment.

To achieve this aim, the following tasks are defined:

1. To substantiate the feasibility of creating its own Financial Investigation Agency at the enterprise and de- velop its organizational structure and functions.

2. To propose the stages of revealing the facts of abuse.

3. To identify the falsification of financial reporting in financial fraud and justify the monitoring of fraud risks with financial reporting for the entity, risk ranking and quantitative and qualitative forms of control.

\section{Research of existing solutions of the problem}

Many foreign theoreticians and practitioners, as well as audit companies (Deloitte, PwC, Ernst \& Young, KPMG) and public organizations on accounting and audit are en- gaged in the problem of corporate fraud, including falsifi- cation of corporate financial reporting. For example, some authors [12] point out that in the financial investigation of fraud, it is necessary first of all to investigate the psy- chology and factors that contribute to the risk of fraud in the enterprise, and they indicate the potential mistakes that management and auditors may have in suspecting employees of wrongful actions. Other specialists [13, 14] describe the schemes of misrepresentation of accounting data and reporting, stressing that knowledge of such schemes in the process of analyzing financial statements in the conduct of financial investigations are necessary to iden- tify fraud. Some researchers [15] give examples of the formation of a plan for financial investigations, methods of collecting and protecting information, and also note the main features of forged documents. Some authors point to the problems of interaction between internal audit and financial investigation [5], and also reveal the facts of fraud with incomes and accounts receivable [16]. In work [6] the author dwells in detail on the inspection of the ex-penses of the enterprise with the purpose of revealing fraud, and also notes that it is impossible to carry out financial investigations of fraud at the enterprise without the means of criminalistics. It should be noted and the growing interest in this issue in the consulting and legal practice, as well as in domestic scientific literature. In work [17] the modern state of manipulation of indicators of financial reporting at domestic enterprises is investigated and methods of identification of manipulation of account- ing records are defined. The author of the article [18] discloses the essence of the internal audit of fraud through the process of identifying the signs of fraud in order to timely prevent fraudulent actions and manipulation of credentials that could lead to bankruptcy of the joint-stock company or its absorption by other enterprises as a result of inefficient managerial decisions. The article [19] analyzes the role of internal auditors in the prevention and detection of fraud, emphasizes the psychological component of the activity of the internal auditor and proves the exis- tence of a correlation between the level of responsibility and skepticism and the quality of fraud risk assessment by the internal auditor.

\section{Methods of research}

To solve the problems, the following methods are used: analysis and synthesis, logical generalization, comparative comparison.

\section{Research results}

As the study showed, the actual issue for each enter- prise today is the problem of identifying and combating abuses. This is due to the fact that despite the constant development of internal control and audit systems, business losses from fraud at enterprises grow annually (Table 1).

Table 1

The ACFE investigation on fraud in enterprises in 2016 (collectively based on [1])

\begin{tabular}{|c|l|c|c|}
\hline № & \multicolumn{1}{|c|}{ Indicator } & Unit & Value \\
\hline 1 & $\begin{array}{l}\text { Loss of revenue of the average enterprise } \\
\text { from fraud in the year }\end{array}$ & $\%$ & minimum 5 \\
\hline 2 & $\begin{array}{l}\text { Total amount of financial losses from } \\
\text { fraud in the enterprise }\end{array}$ & Billion. \$ & More than 6.3 \\
\hline 3 & $\begin{array}{l}\text { Average amount of fraud loss in the } \\
\text { enterprise }\end{array}$ & $\$$ & 150000 \\
\hline 4 & $\begin{array}{l}\text { The average loss rate for one fraud in } \\
\text { the enterprise }\end{array}$ & million \$ & 2.7 \\
\hline 5 & $\begin{array}{l}\text { Average damage to the state from fraud } \\
\text { events in enterprises that occurred at the } \\
\text { national level }\end{array}$ & $\$$ & 194000 \\
\hline 6 & $\begin{array}{l}\text { Average damage to the state from fraud } \\
\text { events in enterprises that occurred at the } \\
\text { regional level }\end{array}$ & $\$$ & 100000 \\
\hline 7 & $\begin{array}{l}\text { Average damage to the state from fraud } \\
\text { events that occurred at local enterprises }\end{array}$ & $\$$ & 8000 \\
\hline
\end{tabular}

In this context, let's note that: first, there is a le- gal [20] and economic (accounting) [21] approaches to the definition of «fraud» concept. A legal study of this concept makes it clear:

1) the subject of fraud: property (money, valuables, etc.) and the right to property (the right to property is usually fixed by a certain document, in the following it allows the intruder to get the property in his property);

2) the ways of fraudulent: fraud and abuse of trust;

3) signs of fraud - these are qualifying signs for determining the composition of fraud as a type of crime [20,22].

In accounting practice, fraud is considered, on the one hand, when it comes to errors or falsification of accounting and reporting data (this is established by the auditors), and on the other hand - characterized by the cumulative actual signs of the crime in the decision-making system and key business processes by which it is possible to iden- tify the available facts of fraud by one or more persons from management personnel in the corporate governance system (legal understanding) [21-24]. It is believed that the most effective method of preventing corporate fraud 
is the financial security services (financial investigations, internal audit, internal control and forensic departments) in enterprises interact with external experts. Thus, European companies spend 0.5 to $1 \%$ of financial turnover on business security, Ukrainian companies spend less than $0.1 \%$ [2]. Taking into account the existing achievements of Ukrainian and foreign researchers, as well as the world experience in counteracting this negative phenomenon $[2,6,7,10,13]$, it is proposed to form a system of internal security of business and counteracting fraud by creating at the enterprise the Financial Investigation Agency itself (to formalize it, as a separate legal entity), headed, for example, by the Deputy Financial Director for controlling and, which for all strategic and operational matters reports to the top management of the enterprise (for example, with regard to decisions on suspected persons, on transferring cases to law enforcement bodies, etc.), and on organizational matters to the financial director (for example, organization and methods of work, etc.), the Agency also interacts with the risk service (fraud risk assessment) and the legal department (evaluation of contracts). Agency staff is certified specialists in finance, audit, accounting and management accounting, psycholo- gists and programmers. The agency includes the following services: information and analytical control, internal audit, financial investigations and psychological prevention of vio- lations. The organizational structure and functions of each service are shown in Fig. 1.

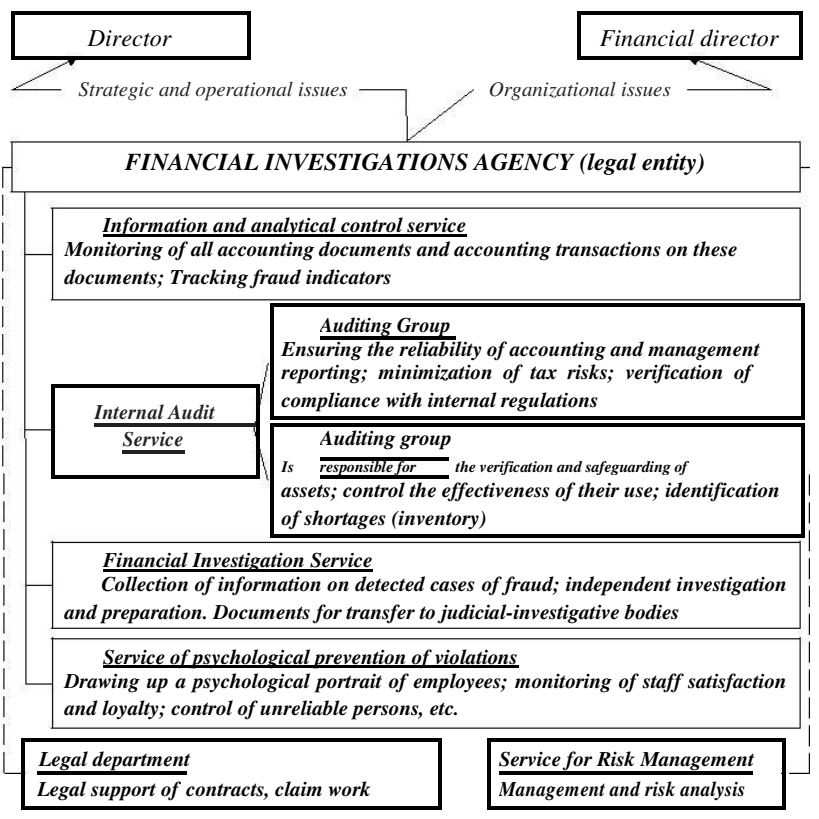

Fig. 1. System of internal security of business and counteracting fraud (developed by the author on the basis of $[4,6,15,22]$ )

The identification of the facts of abuse and their analysis is suggested for the following stages:

Stage 1. Drawing up a table of abuse indicators (Table 2) and a library of typical schemes of fraud and abuse (Table 3), which is replenished as needed monthly and sources of new data which may be: internal audit reports, audits, security service activities, management information and experts (for example, an expert on the audit of quality management systems or information security). At this stage, it is necessary to identify business processes where there is more risk of fraud, create a list of fraud scenarios in the context of these business processes and develop cer- tain indicators of abuse, create a condensed format for the reporting system.

Table 2

Abuse indicators (fragment) (developed by the author on the basis of $[4,9,11,16]$ )

\begin{tabular}{|c|c|c|}
\hline № & Indicator & Explanation \\
\hline 1 & \multicolumn{2}{|r|}{ Business process - implementation } \\
\hline 1.1 & $\begin{array}{l}\text { Special discounts for } \\
\text { buyers }\end{array}$ & $\begin{array}{l}\text { The maximum size and types of discounts are } \\
\text { approved in the marketing policy of the enter- } \\
\text { prise, in practice sales managers, provided that } \\
\text { the client is particularly important for the en- } \\
\text { terprise and the agreement with it will bring } \\
\text { income, can provide higher discounts, in this } \\
\text { case it is necessary to check the gross profit } \\
\text { margin for the transaction and If it is negative, } \\
\text { require explanations from the manager }\end{array}$ \\
\hline 1.2 & $\begin{array}{l}\text { Increase in overdue } \\
\text { accounts receivable }\end{array}$ & $\begin{array}{l}\text { A decrease in the turnover of receivables may } \\
\text { indirectly indicate that the company's balance sheet } \\
\text { has a large number of fictitious debtors. In the } \\
\text { event of overdue accounts receivable, it is neces- } \\
\text { sary to verify the correctness of the shipment in } \\
\text { the accounting, and then, together with the sales } \\
\text { managers, work out a plan for repaying the debt }\end{array}$ \\
\hline 2 & \multicolumn{2}{|r|}{ Business process - purchase } \\
\hline 2.1 & $\begin{array}{l}\text { Deviation of purchas- } \\
\text { ing prices from aver- } \\
\text { age market prices }\end{array}$ & $\begin{array}{l}\text { If there are suspiciously high purchase prices } \\
\text { for a contract that has not yet been signed (the } \\
\text { difference between contractual and average mar- } \\
\text { ket prices exceeds } 20 \% \text { ), while the purchasing } \\
\text { manager insists that the cost of supply is optimal }\end{array}$ \\
\hline 3 & \multicolumn{2}{|r|}{ Business process - production } \\
\hline 3.1 & $\begin{array}{l}\text { Deviation of the ac- } \\
\text { tual cost price from } \\
\text { the planned }\end{array}$ & $\begin{array}{l}\text { Costing is carried out by mistake, or extra costs } \\
\text { are written off at cost }\end{array}$ \\
\hline 3.2 & $\begin{array}{l}\text { Increase in the re- } \\
\text { ceipt of raw mate- } \\
\text { rials in production } \\
\text { leads to an increase } \\
\text { in the volume of fin- } \\
\text { ished products and } \\
\text { production waste }\end{array}$ & $\begin{array}{l}\text { If this does not happen - it is possible that the } \\
\text { cause is theft }\end{array}$ \\
\hline 4 & \multicolumn{2}{|r|}{ Contradictions in financial indicators } \\
\hline 4.1 & $\begin{array}{l}\text { The rate of decline in } \\
\text { the share of marginal } \\
\text { revenue in revenue. } \\
\text { Revenue growth rate } \\
\end{array}$ & $\begin{array}{l}\text { If the sales revenue grows (the rate of revenue } \\
\text { growth is greater than one), and the share of mar- } \\
\text { ginal income in revenue decreases (the rate of de- } \\
\text { crease in marginal income is greater than one), then } \\
\text { there are signs of fraud in the financial statements }\end{array}$ \\
\hline 4.2 & $\begin{array}{l}\text { The growth rate of } \\
\text { asset quality }\end{array}$ & $\begin{array}{l}\text { If the growth rate of asset quality exceeds one, then, } \\
\text { most likely, the enterprise increases the share of } \\
\text { non-current assets in the total volume of assets. If } \\
\text { the growth of non-current assets is not related to } \\
\text { an increase in the number of fixed assets, this may } \\
\text { indicate an unjustified capitalization of expenses }\end{array}$ \\
\hline 4.3 & $\begin{array}{l}\text { The growth rate of } \\
\text { receivables turnover }\end{array}$ & $\begin{array}{l}\text { When the turnover of receivables sharply increases, } \\
\text { then it is likely that manipulations with proceeds } \\
\text { from sales are being made; When the turnover of } \\
\text { receivables is sharply reduced, it can't be excluded } \\
\text { that the receivables are artificially overstated }\end{array}$ \\
\hline 4.4 & $\begin{array}{l}\text { The growth rate of } \\
\text { the share of expens- } \\
\text { es in sales revenue }\end{array}$ & $\begin{array}{l}\text { If there is a significant deviation from the unit, } \\
\text { then manipulation or cost, or with revenue }\end{array}$ \\
\hline 4.5 & $\begin{array}{l}\text { The growth rate of } \\
\text { the financial lever- } \\
\text { age }\end{array}$ & $\begin{array}{l}\text { If the growth rate of the financial leverage fluc- } \\
\text { tuates significantly, it is possible that accounts } \\
\text { payable are included in profits, that is, an artificial } \\
\text { understating of the level of financial leverage } \\
\text { leads to an increase in the market value }\end{array}$ \\
\hline 4.6 & $\begin{array}{l}\text { The growth rate of } \\
\text { the share of depre- } \\
\text { ciation charges }\end{array}$ & $\begin{array}{l}\text { The growth rate of the share of depreciation is } \\
\text { approximately equal to unity, if there are sharp } \\
\text { changes in this indicator, one can assert about } \\
\text { possible fraud in the financial statements }\end{array}$ \\
\hline
\end{tabular}


Structure of the library of typical schemes of fraud and abuse (fragment on theft) (systematized by the author on the basis of $[13,14,25,26])$

\begin{tabular}{|c|c|}
\hline Indicator & Feature \\
\hline Signs of abuse & $\begin{array}{l}\text { Absence of documents confirming the work/tender; conclusion of an agreement on the performance of work with an enterprise } \\
\text { that is not known in the profile market; insufficient details of the terms of the contract (the contract does not contain a list of } \\
\text { services, there are no measurable units, etc.); overstated compared to the average market value of the services of the contrac- } \\
\text { tor; lack of justification for the need to involve the contractor in the work with own resources; affiliation of the contracting } \\
\text { enterprise with the responsible persons of the enterprise-customer; the absence of a contractor at the registration address } \\
\text { and so on }\end{array}$ \\
\hline Factors of abuse & Conditions that can lead to abuse, they can be divided into three groups: opportunity, motivation and self-justification \\
\hline Evidence of abuse & $\begin{array}{l}\text { The coincidence of data in the acts of the contractor and reports on the work performed by own personnel (work orders); } \\
\text { the absence of the result of the works accepted under the act and paid to the contractor; violation of the approved procedure } \\
\text { for concluding a contract (no tender was conducted, the agreement was not coordinated with the parent organization), etc. }\end{array}$ \\
\hline $\begin{array}{l}\text { Probable patterns of } \\
\text { abuse }\end{array}$ & $\begin{array}{l}\text { The most likely ways of committing wrongful acts with the available signs and factors of abuse. For example, an enterprise } \\
\text { enters into a contract for the performance of work with a contractor, who actually does not have the resources to perform } \\
\text { these works. The work is done on its own, but the reports on their implementation are transferred to the contractor and copied } \\
\text { to the acts of performed work. Based on the acts, the contractor's services are paid }\end{array}$ \\
\hline Possible stakeholders & For each scheme of abuse, a list of persons who may be involved in the crime is listed: initiator; offender \\
\hline $\begin{array}{l}\text { Methods of gathering } \\
\text { evidence and conduc- } \\
\text { ting investigations }\end{array}$ & $\begin{array}{l}\text { Depending on the alleged scheme of abuse, the investigation methodology is also developed, including methods for clarifying } \\
\text { the circumstances of the crime, identifying the persons involved and assessing the caused damage; the possible sources of } \\
\text { information and evidence are listed: a list of documents that need to be analyzed (and, if necessary, included in the evidence } \\
\text { base), the subject of analysis, from the staff for interviewing. For example, internal correspondence is analyzed to attract and } \\
\text { select a contractor, this allows to identify the initiator of the transfer of work to the party and the one which proposed the } \\
\text { nominee of the contractor; analysis of documentation on the contract of work helps identify people who have agreed the terms } \\
\text { of the contract; verification of acts of completed work - signatures on fictitious documents; The amount of damage (the cost } \\
\text { of duplicated works) is estimated based on the reconciliation of the contractor's activities and work reports on the enterprise, } \\
\text { and the like }\end{array}$ \\
\hline
\end{tabular}

All employees of the internal control and audit ser- vice have free access to the Library of Fraud and Abuse Schemes, and employees of other services can receive it only after a special agreement.

Stage 2. Implementation of the control system. The developed tables of indicators of abuse are reported to departments, divisions, branches, etc., which are filled out by employees and the results are analyzed, and it should be borne in mind that violations can be detected only when analyzing related indicators and comparing the re- sults of previous periods with current and extrapolating it to the future.

Stage 3. Systematic identification of abuses and shortcomings - continuous monitoring of the enterprise's organizational environment in terms of risk tracking, pro- vides for implementation at all levels of management of individual responsibility for identifying possible threats and their assessment.

Stage 4. Development of motivation system. The system of evaluation of effectiveness and motivation is developed according to plan-fact analysis data and the rules for awarding and fining are determined in advance and are available for study to all employees.

Secondly, based on the studies (Table 4) conducted by KPMG in 2016 for the CIS countries, it is possible to note that one of the departments most susceptible to fraud is the Finance and Accounting Department $(20 \%)$ and one of the types of fraud, namely financial fraud fal- sification of financial statements (11\%) and this, first of all, harms users of reporting, misleading them, as a result of which wrong decisions are made. It is from this type of financial fraud that the losses for the enterprise are the most significant, since it is extremely difficult to identify and prevent the distortion of accounting data and falsification of financial statements, because in ad- dition to deliberate distortions, there are also cognitive distortions in conditions of ambiguity, that is, distortions that are the result of conflicts of professional judgments on the application of regulations and accounting regula- tions (assessment and methodology for the reflection of assets, liabilities, income and expenses in accounting are based on subjective judgments, assumptions). Therefore, it is important to identify, rank and evaluate potential risks of falsification of financial statements, as well as to develop mechanisms to reduce the risk of falsification of financial statements due to conflicts of professional judg- ment. In this regard, let's propose a table of risks that can arise from fraudulent financial reporting (Table 5), as well as control over the risks of falsification of financial statements and misrepresentation of accounting data with a fundamental qualitative characteristic «essence», the essence of it is the focus of inspections and evaluation- both the meaning and nature of the distortions, that is simultaneously carried out, both quantitative and quali- tative control.

In the process of quantitative control, foreign com- panies apply the Trail Balance Review, which involves identifying deviations in the most significant articles of reporting compared to the previous reporting period, with attention paid only to those deviations that, based on practical studies by foreign experts, exceed $10 \%$ level. The technique of qualitative control can be formed on the basis of recommendations developed by SOX (Sarbanes-Oxley Low) [19]. 
The KPMG survey in 2016 on corporate fraud in the CIS countries (generalized by the author on the basis of [3])

\begin{tabular}{|c|c|c|}
\hline № & Indicator & Value, $\%$ \\
\hline 1 & \multicolumn{2}{|c|}{ Factors contributing to fraud } \\
\hline 1.1 & There is no (or ineffective) internal control system & 71 \\
\hline 1.2 & Bad faith of employees & 16 \\
\hline 1.3 & Deficiencies in the internal control system & 10 \\
\hline 1.4 & Other & 3 \\
\hline 2 & \multicolumn{2}{|c|}{ Departments and bodies are most susceptible to fraudulent actions } \\
\hline 2.1 & Executive agency & 24 \\
\hline 2.2 & Purchasing department & 22 \\
\hline 2.3 & Department of Finance and Accounting & 20 \\
\hline 2.4 & Sales department & 14 \\
\hline 2.5 & Operating department & 8 \\
\hline 2.6 & Governing body & 4 \\
\hline 2.7 & Administrative department & 2 \\
\hline 2.8 & IT department & 2 \\
\hline 2.9 & Human Resources Department & 2 \\
\hline 2.10 & Marketing department & 2 \\
\hline 3 & \multicolumn{2}{|c|}{ Types of Intra-corporate fraud } \\
\hline 3.1 & Misappropriation of assets & 24 \\
\hline 3.2 & Illegal receipt of income or acquisition of assets & 22 \\
\hline 3.3 & Falsification of financial statements & 11 \\
\hline 3.4 & Corruption & 11 \\
\hline 3.5 & Manipulation of expenses or liabilities & 9 \\
\hline 3.6 & Other wrongful acts & 6 \\
\hline 3.7 & Theft of business & 6 \\
\hline 3.8 & Violation of regulatory bodies & 4 \\
\hline 3.9 & Other & 3 \\
\hline 3.10 & Illegal seizure of information & 2 \\
\hline 3.11 & Commercial sabotage & 2 \\
\hline 4 & \multicolumn{2}{|c|}{ Methods of falsifying financial reporting } \\
\hline 4.1 & Improper recognition of revenue & 31 \\
\hline 4.2 & Other & 24 \\
\hline 4.3 & Incorrect reflection of expenses & 16 \\
\hline 4.4 & Overvaluation of assets & 14 \\
\hline 4.5 & Distorted capitalization & 5 \\
\hline 4.6 & Understatement of expenses & 5 \\
\hline 4.7 & Understatement of obligations & 5 \\
\hline
\end{tabular}

Risks of fraud with financial reporting (systematized by the author on the basis of [25-28])

Table 5

\begin{tabular}{|c|c|c|c|c|c|}
\hline № & Risks of Level 2 & \multicolumn{4}{|c|}{ Factors/signs of risk } \\
\hline 1 & \multicolumn{5}{|c|}{ 1-level: The risk of manipulating legislation } \\
\hline 1.1 & Risk of tax offenses & \multirow{2}{*}{$\begin{array}{l}\text { Violation of accounting rules } \\
\text { for NP (S) A and IASB }\end{array}$} & $\begin{array}{c}\text { The failure of the tax agent } \\
\text { to fulfill obligations for the } \\
\text { assessment, withholding and } \\
\text { transfer of taxes }\end{array}$ & $\begin{array}{c}\text { The concealment of the com- } \\
\text { pany's funds at the expense of } \\
\text { which the tax arrears must be } \\
\text { recovered }\end{array}$ & Misinterpretation of legislation \\
\hline 1.2 & $\begin{array}{c}\text { Risk of violation of } \\
\text { accounting rules and } \\
\text { presentation of financial } \\
\text { statements }\end{array}$ & & $\begin{array}{l}\text { Incorrect interpretation of NP } \\
\text { (S) A and IASB principles }\end{array}$ & $\begin{array}{l}\text { Incorrect accounting policy } \\
\text { formation }\end{array}$ & $\begin{array}{l}\text { Not compliance with account- } \\
\text { ing technology in accordance } \\
\text { with accounting policies }\end{array}$ \\
\hline 2 & \multicolumn{5}{|c|}{ Level 1: The risk of account manipulation } \\
\hline 2.1 & $\begin{array}{l}\text { The risk of deliberately } \\
\text { false accounting entries in } \\
\text { relation to primary docu- } \\
\text { ments and accounting rules }\end{array}$ & \begin{tabular}{|l|} 
Unreasonable accounts, en- \\
tries in accounting registers \\
do not correspond to the con- \\
tents of primary documents
\end{tabular} & $\begin{array}{l}\text { Accounting records on ac- } \\
\text { counts of accounting are not } \\
\text { confirmed by the corres- } \\
\text { ponding primary documents }\end{array}$ & $\begin{array}{c}\text { Availability of duplicate } \\
\text { documents, which reflect the } \\
\text { transfer of identical amounts } \\
\text { to the same counterparty }\end{array}$ & $\begin{array}{c}\text { Pass-through or local } \\
\text { knowingly false accounts, } \\
\text { incorrect correspondence } \\
\text { of accounts } \\
\end{array}$ \\
\hline 2.2 & $\begin{array}{c}\text { Risk of misstatement of } \\
\text { accounts }\end{array}$ & $\begin{array}{c}\text { A large number of corrective } \\
\text { entries in the accounting } \\
\text { registers }\end{array}$ & $\begin{array}{l}\text { Incorrect correspondence of } \\
\text { accounts }\end{array}$ & $\begin{array}{l}\text { Discrepancy between data on } \\
\text { interrelated forms of financial } \\
\text { reporting }\end{array}$ & $\begin{array}{l}\text { Reversed balances on active- } \\
\text { passive accounts }\end{array}$ \\
\hline 3 & \multicolumn{5}{|c|}{ 1-level: Risk of falsification of documents } \\
\hline 3.1 & $\begin{array}{l}\text { Risk of falsification of } \\
\text { primary documents and } \\
\text { accounting registers }\end{array}$ & $\begin{array}{l}\text { Intentional distortion of the } \\
\text { contents, requisites of the } \\
\text { document (this may be } \\
\text { a forgery of the entire docu- } \\
\text { ment or part thereof) }\end{array}$ & $\begin{array}{l}\text { The balance and turnover on } \\
\text { synthetic and analytical ac- } \\
\text { counts do not coincide }\end{array}$ & $\begin{array}{l}\text { The reporting items reflect in- } \\
\text { formation on the balance sheet } \\
\text { accounts or vice versa }\end{array}$ & $\begin{array}{c}\text { Not all information in accor- } \\
\text { dance with NP (C) BU NP (S) } \\
\text { A and IASB is disclosed in the } \\
\text { financial statements }\end{array}$ \\
\hline 4 & \multicolumn{5}{|c|}{ 1-level: The risk of imaginary transactions } \\
\hline 4.1 & $\begin{array}{l}\text { Risk of transactions with } \\
\text { one-day firms }\end{array}$ & Signing fictitious contracts & $\begin{array}{l}\text { Transfer of funds to the } \\
\text { contractor for work performed } \\
\text { on their own }\end{array}$ & $\begin{array}{l}\text { Transfer of funds in the ab- } \\
\text { sence of acceptance papers }\end{array}$ & $\begin{array}{l}\text { Absence of the company } \\
\text { at the registration address }\end{array}$ \\
\hline
\end{tabular}




\section{SWOT analysis if research results}

Strengths. The strength of research is the rationale for the creation of its own agency for the financial investigation of corporate fraud at the enterprise. Based on the analysis of the experience of the operation of such units in foreign companies, the organizational structure, agency functions and stages of revealing abuses in the enterprise are proposed. A table of indicators has been developed and fragment of the structure of the library of typical schemes of fraud and abuse, which can be used not only to detect fraud, but also to identify, rank and evaluate potential risks, their factors, response measures to abuse, and the establishment of a risk management and control system. The risks of fraud with financial statements and their factors/signs are considered.

Weaknesses. Weakness is that, under the conditions of the development of computer technologies and changing legislation, new fraudulent schemes appear, including falsi- fication of financial statements, so it is necessary to take into account not only the experience of foreign experts and leading audit companies to investigate financial abuses at enterprises but also domestic experience Financial in- vestigation requires detailed analysis, but unfortunately Ukrainian audit companies do not provide such information.

Opportunities. Opportunities for further research is the study of the risks of cognitive distortion in the context of ambiguity in the interpretation of accounting regulations.

Threats. Threats to the results of conducted research is that the Ukrainian legislative system has significant short- comings in identifying obstacles to the implementation of falsification of financial statements, both at a regulatory level and in establishing accountability for fraud in accounting.

\section{Conclusions}

1. The expediency of creating its own Financial Investigation Agency at the enterprise is substantiated and its organizational structure is developed, which includes the following services: information and analytical control, internal audit, financial investigations and psychological prevention of violations. The functions of these services are defined.

2. The stages of revealing the facts of abuse are sug- gested. In this regard, a table of abuse indicators and a library structure of typical fraud schemes and abuses against embezzlement is developed.

3. The place of falsification of financial reporting in financial fraud and justifiable control of fraud risks with financial reporting for the entity, risk ranking and quan- titative and qualitative forms of control is determined. A table of risks that can arise when fraudulent financial reporting is proposed.

\section{References}

1. Issledovanie ACFE o moshennichestve v 2016 godu. Obshchie dannye [Electronic resource] // HR-Security. - Available at: Iwww/ URL: http://hr-security.ua/acfe-survey-2016-part-1

2. Ukraintsy ukrali u svoih rabotodatelei $\$ 5,5$ mlrd. [Electronic resource] // Segodnia. - September 24, 2014. - Available at: Iwww/URL: http://www.segodnya.ua/economics/business/ ukraincyukrali-u-svoih-rabotodateley-55-mlrd-554767.htm

3. «Portret sovremennogo korporativnogo moshennika-2016»: rezul'taty issledovaniia KPMG [Electronic resource] // KPMG. - Available at: Iwww/URL: https://assets.kpmg.com/content/ dam/kpmg/ru/pdf/2016/12/ru-ru-profiles-of-the-fraudster-russia-andthe-cis.pdf
4. Anderson, D. J. Leveraging COSO across the three lines of defense [Electronic resource] / D. J. Anderson, G. Eubanks. - Committee of Sponsoring Organizations of the Treadway Com- mission, 2015. Available at: Iwww/URL: https://www.coso.org/ Documents/COSO2015-3LOD.pdf

5. Bartolucci, D. D. Internal Audit: The Second Line of Defen- se [Text] / D. D. Bartolucci, T. M. Bobek, J. A. LaTorre // A Guide to Forensic Accounting Investigation. - John Wiley \& Sons, Inc., 2015. - P. 95 113. doi:10.1002/9781119200048.ch6

6. Manning, G. Financial Investigation and Forensic Accounting Second Edition [Text] / G. Manning. - CRC Press, 2005. - 600 p doi:10.1201/9781420039061

7. Pasco, G. A. Criminal Financial Investigations: The Use of Forensic Accounting Techniques and Indirect Methods of Proof, Second Edition [Text] / G. A. Pasco. - CRC Press, 2012. - 295 p.

8. Oyedokun, G. E. Forensic Investigation and Forensic Audit Methodology in a Computerized Work Environment [Text] /

G. E. Oyedokun // SSRN Electronic Journal. - 2015. - P. 1-20. doi:10.2139/ssrn.2593263

9. Oyedokun, G. E. Best Practices in Conducting Financial Investigations in a Cashed-Based Economy \& Tax Implications [Elec- tronic resource] / G. E. Oyedokun // SSRN Electronic Journal. - 2014. - P 1-22. doi:10.2139/ssrn.2448427

10. Dorrell, D. D. Financial Forensics Body of Knowledge [Text] / D. D. Dorrell, G. A. Gadawski. - John Wiley \& Sons, Inc., 2012. 541 p. doi:10.1002/9781119200734

11. Dutta, S. K. Statistical Techniques for Forensic Accounting Understanding the Theory and Application of Data Analysis [Text] / S. K. Dutta. - FT Press, 2013. - 288 p.

12. Golden, T. W. Psychology of the Fraudster [Text] / T. W. Gol- den // A Guide to Forensic Accounting Investigation. - John Wiley \& Sons, Inc., 2015. - P. 25-35. doi:10.1002/9781119200048.ch2

13. Dooley, D. V. Financial Reporting Fraud and the Capital Markets [Text] / D. V. Dooley, S. L. Skalak // A Guide to Forensic Accounting Investigation. - John Wiley \& Sons, Inc., 2015. - P. 417 431. doi:10.1002/9781119200048.ch21

14. Frank, J. J. Financial Statement Fraud: Other Schemes and Misappropriations [Text] / J. J. Frank, D. Jansen, M. Carey // A Guide to Forensic Accounting Investigation. - John Wiley \& Sons, Inc., 2015. - P. 467-494. doi:10.1002/9781119200048.ch23

15. Clayton, M. M. Investigative Techniques [Text] / M. M. Clay- ton // A Guide to Forensic Accounting Investigation. - John Wiley \& Sons, Inc., 2015. - P. 271-291. doi:10.1002/9781119200048.ch14

16. Frank, J. J. Financial Statement Fraud: Revenue and Receivables [Text] / J. J. Frank, D. Jansen, J. Ahmad, M. Carey // A Guide to Forensic Accounting Investigation. - John Wiley \& Sons, Inc., 2015. - P. 433-466. doi:10.1002/9781119200048.ch22

17. Proskurina, N. M. Manipuliuvannia finansovymy rezultatamy: peredumovy, oznaky ta sposoby vyiavlennia [Text] / N. M. Prosku- rina // Problemy i perspektyvy rozvytku pidpryiemnytstva. - 2014. - No. 1. - P. 110-114

18. Smetanko, O. The essence of internal audit of fraud in the sys- tem of corporate management of joint-stock companies [Text] /

O. Smetanko // Economy. Finances. Management: actual issues of science and practical activity. -2015 . - No. 3. - P. 22-30.

19. Shestakova, O. Responsibility and skepticism of internal auditors- in fraud risks' assessment [Text] / O. Shestakova // Ekono- mist. - 2014 - No. 2. - P. 54-56.

20. Criminal Code of Ukraine [Electronic resource]: Law of Ukraine from 05.04.2001 No. 2341-III. - Available at: Iwww/URL: http://zakon2.rada.gov.ua/laws/show/2341-14

21. MSA 240 «Vidpovidalnist audytriv, shcho stosuietsia shakhra- istva, pry audyti finansovoi zvitnosti» [Electronic resource] // International Institute of Audit. - Available at: Iwww/URL: http://www.mia.kiev.ua/ru/isa.html

22. Syrotjuk, A. The role of auditing in revealing the fraudulent activities [Text] / A. Syrotjuk, L. Petryshyn // Ahrarna eko- nomika. - 2012. Vol. 5, No. 3-4. - P. 38-42.

23. Rohoznyi, S. Pomylky ta rezultaty shakhraistva u finansovii zvitnosti [Electronic resource] / S. Rohoznyi // Visnyk MSFZ. - 
2015. - No. 11. - Available at: Iwww/URL: http://ifrs.ligazakon.ua/ua/magazine_article/FZ000628

24. Mykhalchyshyna, L. G. Internal audit is in prevention of errors and swindle on enterprise [Text] / L. G. Mykhalchyshyna, V. Kalashnik // Proceedings of VNAU. A series of economic science. - 2012. - No. 2 (64). - P. 94-99.

25. Managing the Business Risk of Fraud: A Practical Guide [Elec- tronic resource] // The Institute of Internal Auditors. - Avail- able at: Iwww/URL: https://na.theiia.org/standards-guidance/ Public\%20Documents/fraud\%20paper.pdf

26. Fraud Resources Library [Electronic resource] // Association of Certified Fraud Examiners. - Available at: Iwww/URL: http://www.acfe.com/resource-library.aspx

27. Institute of Internal Auditors of Ukraine [Electronic resource]. Available at: Iwww/URL: https://www.iia.org.ua

28. Anonsy zakhodiv [Electronic resource] // Association of Corpo- rate Security Professionals. - Available at: Iwww/URL: http:// corporatesecurity.org.ua/uk-UA/Anonsy-zahodiv/

\section{Исследование противодействия корпоративному} мошенничеству: бухгалтерско-юридические подходы к выявлению злоупотреблений

Предложено создание собственного агентства по финан- совым расследованиям на предприятии, его организационная структура, функции, этапы выявления фактов злоупотреблений

и таблица индикаторов злоупотреблений. Определено место фальсификации финансовой отчетности в финансовом мошенничестве. Обоснована необходимость оценки риска фальсификации финансовой отчетности и приведены наиболее существенные риски мошенничества с финансовой отчетностью.

Ключевые слова: корпоративное мошенничество, фальсификация финансовой отчетности, оценка рисков мошенничества, Агентство финансовых расследований.

Plikus Iryna, PhD, Associate Professor, Department of Finance and Credit, Sumy State University, Ukraine, e-mail: plikusirina@gmail.com, ORCID: http://orcid.org/0000-0002-0657-7260

"I certify that I have the right to deposit the contribution with MPRA" 